\title{
FRANCUSKI PLAN OŻYWIENIA GOSPODARKI (2008-2010) - WIZJE I RZECZYWISTOŚĆ ${ }^{1}$
}

\begin{abstract}
Streszczenie
Cel - Celem artykułu jest przedstawienie francuskiego planu ożywienia gospodarki, który był odpowiedzią na światowy kryzys finansowy z lat 2007-2008.

Opis - W tekście omówiono założenia plan de relance, jego realizację na poziomie poszczególnych programów oraz dokonano próby oceny jego skuteczności z punktu widzenia kosztów. Rozważania przeprowadzono na podstawie dokumentów i opracowań francuskiego Ministerstwa Gospodarki i Finansów.

Wynik - Analizując jego poszczególne podprogramy uwydatniaja się znaczące dysproporcje w stopniu ich realizacji. Przywołane w tekście badania niezależnych instytucji pokazuja, że całościowy koszt wprowadzenia planu ożywienia gospodarki przewyższał znacząco jego prognozowany wpływ na PKB.
\end{abstract}

Słowa kluczowe: kryzys ekonomiczny we Francji, francuski plan ożywienia gospodarki, francuska polityka antykryzysowa

\section{FRENCH ECONOMIC RECOVERY PLAN (2008-2010) - VISIONS AND REALITY}

\section{Summary}

Purpose - The main aim of the following paper is to describe the French plan for economic recovery which was the response to the global economic crisis in 2007-2008.

Description - The concept of plan de relance, realization of its particular programs and the attempt to apprise its efficiency from the cost point of view have been analyzed. Through the analysis of these particular sub-programmes we can clearly see an important disproportion in the extent of their realization.

Finding - The referred research of independent institutions show that the final cost of the economy recovery plan introduction was significantly higher than the forecasted impact on GDP. The following consideration was based of the records and studies of the French Ministry of Economy and Finance.

Key words: economic crisis in France, French economic recovery plan, French anti-crisis policy

JEL classification: G01

1 Artykuł wpłynął 10 sierpnia 2018 r., zaakceptowano 27 września 2018 r.

Article received 10 August 2018, accepted 27 September 2018. 


\section{Wstęp}

Za symboliczny początek globalnego kryzysu finansowego i gospodarczego ${ }^{2}$ uważa się upadek amerykańskiego banku Lehman Brothers 15 września 2008 r. Kryzys szybko przeniósł się ze Stanów Zjednoczonych do Europy w związku $\mathrm{z}$ udziałem europejskich instytucji finansowych w obrocie amerykańskimi aktywami oraz rosnąca niepewnością na światowych rynkach. Francuska gospodarka dotkliwie odczuła skutki załamania się rynku kredytów hipotecznych zanim upadł Lehmann Brothers. Już w sierpniu 2007 r. problemy finansowe miał francuski BNP Paribas zaangażowany na rynku kredytów hipotecznych subprime. W pierwszej kolejności kryzys dotknął instytucje finansowe, jednak ze względu na załamanie się sektora bankowego, miał negatywne następstwa zarówno dla firm, jak i gospodarstw domowych. Do sfery realnej gospodarki dotarł poprzez kanały transmisji kryzysów - powiązania handlowe oraz przepływy kapitałowe. Zmiana oczekiwań wśród francuskich przedsiębiorstw i konsumentów doprowadziła do spadku konsumpcji gospodarstw domowych o 1,4\% w 2009 r. (w latach 2002-2008 średni roczny wzrost wynosił 3,9\%) oraz spadku wartości nakładów brutto na środki trwałe o 9,1\% w 2009 r. (w latach 2002-2008 średni roczny wzrost wynosił 5,17\%) [INSEE, Le produit intérieur brut et ses composantes à prix courants. Odpowiedzią na kryzys był plan ożywienia francuskiej gospodarki (plan de relance de l'économie française), którego założenia przedstawił, w trwającym niemal godzinę przemówieniu, Prezydent Francji N. Sarkozy 4 grudnia 2008 r. w Douai [Sarkozy, 2008]. Celem niniejszego artykułu jest przedstawienie francuskiej polityki antykryzysowej w ramach plan de relance $^{3} \mathrm{z}$ punktu widzenia skuteczności podjętych interwencji oraz ich kosztów. W tym celu konieczne jest udzielenie odpowiedzi na kilka pytań: jakie były założenia planu ożywienia gospodarki, jakie programy stymulujące gospodarkę wprowadzono, w jakim stopniu zrealizowano politykę antykryzysową oraz czy zastosowane mechanizmy okazały się skuteczne?

Podjęcie tego tematu wydaje się zasadne ze względu na ożywioną dyskusję, tocząca się od wielu lat wśród ekonomistów, na temat skuteczności działań antykryzysowych podjętych przez poszczególne rządy i banki centralne oraz ich koszty. Głosy sa podzielone. Część uważa, że interwencje były konieczne, i to im zawdzięczamy ograniczenie negatywnych skutków kryzysu finansowego. Nie brak jednak głosów osób sceptycznie nastawionych do prowadzonej w czasie kryzysu polityki gospodarczej. Bardzo trudno jest jednak przewidzieć jak potoczyłyby się losy poszczególnych krajów, gdyby na całym świecie nie zdecydowano się na ratowanie systemów bankowych i podejmowanie działań antykryzysowych. Bezsporny jest jednak fakt, że we

2 W artykule używane jest pojęcie kryzysu ze względu na powszechne stosowanie tego terminu w opracowaniach francuskich i dyskursie publicznym, mimo że część ekonomistów, twierdzi że nie był to kryzys, lecz recesja.

3 W artykule nie omówiono zagadnienia pomocy rządowej udzielonej francuskiemu sektorowi bankowemu, m.in.: Crédit Agricole, BNP Paribas i grupie Dexia w latach 2008-2009. 
wszystkich krajach objętych kryzysem państwo odgrywało aktywną rolę angażując środki finansowe i próbując przeciwdziałać skutkom kryzysu.

\section{Plan ożywienia gospodarki}

N. Sarkozy w swoim przemówieniu z 4 grudnia 2008 r. użył aż 31 razy słowa inwestycja [Sarkozy, 2008]. To inwestycje, zdaniem Prezydenta Republiki, miały być najlepszym środkiem zaradczym na kryzys. To ich wzrost miał stworzyć warunki do szybkiego i trwałego ożywienia gospodarczego. Kolejnego dnia Prezydent nominował P. Devedjian na urząd ministra ds. wdrożenia planu ożywienia. Plan de relance przyjęty przez radę ministrów 19 grudnia 2008 r. zakładał przeznaczenie 26100000000 euro na ratowanie krajowej gospodarki [Conseil des Ministres ..., 2009, p. 1]. Największa część pieniędzy, bo aż 11600000000 euro, miała poprawić sytuację finansową francuskich przedsiębiorstw przez wzmocnienie systemu poręczeń i gwarancji kredytowych oraz zwiększenie puli udzielanych przez instytucje publiczne kredytów. Inwestycje publiczne miały pochłonąć 10500000000 euro. Z tej kwoty 4000000000 przeznaczone były na bezpośrednie inwestycje państwa w sektory strategiczne: obronę, szkolnictwo wyższe, badania i rozwój. Władze lokalne otrzymały 2500000000 euro w celu zwiększenia pożyczek lub dotacji dla działań inwestycyjnych firm. Kolejne 4000000000 euro zamierzano zainwestować w rozwój wielkich przedsiębiorstw publicznych: kolei, zakładów energetycznych i poczty. Kwota 2000000000 euro miała wesprzeć sektory szczególnie dotknięte skutkami kryzysu: budownictwo i przemysł motoryzacyjny [Budget ..., 2009]. Ostatnie 2000000000 euro miały być przeznaczone na ochronę miejsc pracy oraz wsparcie gospodarstw domowych o najniższych dochodach. Planowany koszt wprowadzenia planu ożywienia gospodarki stanowił około 1,3\% PKB Francji [Commission des finances ..., 2010, p. 2]. Budżet plan de relance przedstawiono na rysunku 1.

Potrzeba realizacji inwestycji publicznych w celu ożywienia francuskiej gospodarki wysunęła na pierwszy plan partnerstwo publiczno-prywatne (PPP). Taka forma współpracy pomiędzy sferą publiczną a podmiotami prywatnymi w czasach kryzysu stała się koniecznością ${ }^{4}$ Rząd francuski w 2009 r. zdecydował się na stworzenie dogodnych warunków do zawierania umów PPP. Już w przemówieniu wygłoszonym w Douai N. Sarkozy zapowiedział udzielenie przez państwo gwarancji na kwotę 10000000000 euro na projekty realizowane w ramach PPP oraz stworzenie publicznego funduszu inwestycyjnego zarządzanego przez Fundusz Depozytów (Caisse des Dépôts et Consignations). Budżet funduszu, wynoszący 8000000000 euro, przeznaczony był na wspieranie projektów infrastrukturalnych w dziedzinie transportu i szkolnictwa wyższego, realizowanych w formule PPP. Trzecim elementem mającym usprawnić zawieranie umów PPP było wprowadzenie 17 lutego 2009 r.

4 Światowy kryzys finansowy i gospodarczy nie zachęcal podmiotów prywatnych do realizacji inwestycji. Formuła PPP, w której ryzyko inwestycyjne podzielone jest pomiędzy partnerów publicznych i prywatnych skłaniała natomiast do ich podejmowania. 
ustawy L'accélération des programmes de construction et d'investissement publics et privés (LAPCIPP), ułatwiającej od strony prawnej ich finansowanie [Devedjian, Lagarde, 2009, s. 2].

RYSUNEK 1

\section{Budżet plan de relance, planowane wydatki w 2009 roku (w mld euro)}

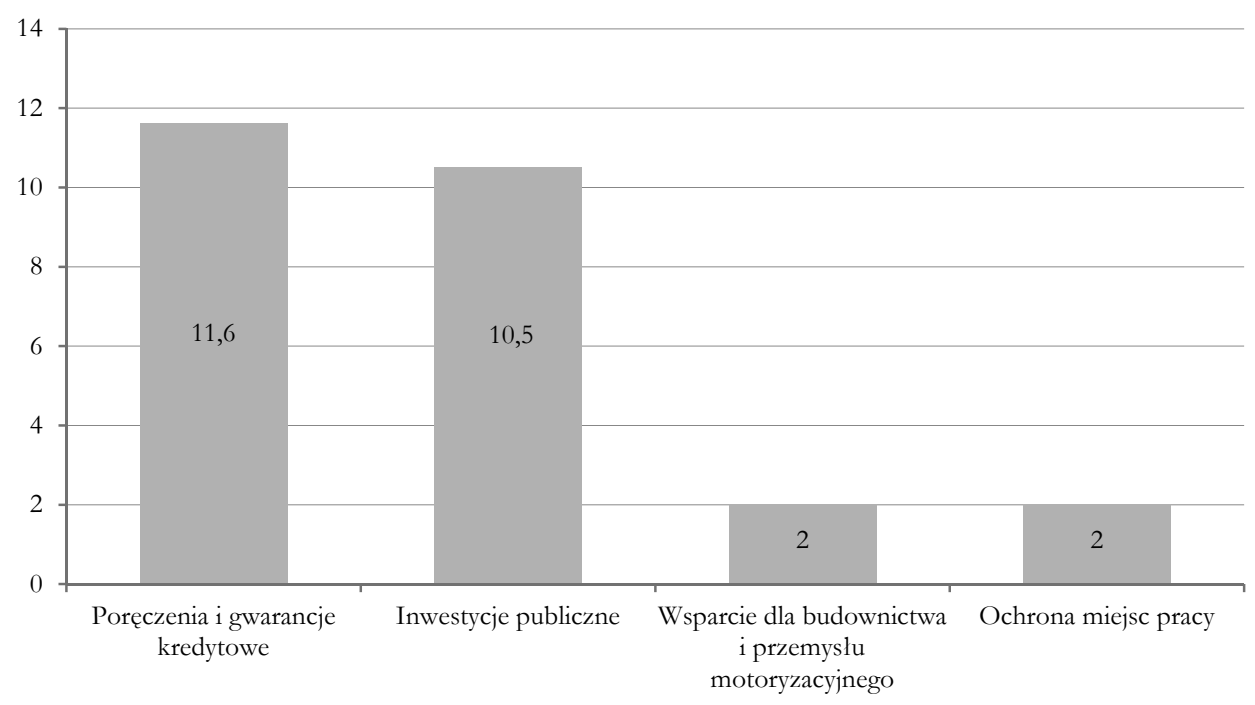

Źródło: [Conseil des Ministres ..., 2009, p. 1].

Gwarancje państwowe na kwotę 10000000000 euro przewidziane były dla kontraktów podpisanych do 31 grudnia 2010 r. Ich celem było łagodzenie negatywnych skutków kryzysu finansowego w kontekście finansowania dotychczasowych przedsięwzięć oraz stymulowanie wzrostu inwestycji. Przyczyniały się one do poczattkowego finansowania projektu lub jego refinansowania. Kontraktami spełniającymi warunki do uzyskania gwarancji były: umowy PPP, umowy o przekazaniu obowiązku użyteczności publicznej (contrats de délégation de service public) oraz koncesje [Devedjian, Lagarde, 2009, s. 2]. Gwarancji udzielano na pożyczki, instrumenty dłużne spółek celowych (sociétés de projet) lub papiery dłużne emitowane przez instytucje kredytowe. Maksymalną wielkość udzielanych gwarancji ustalono na poziomie $80 \%$ kwoty pożyczki lub instrumentów dłużnych.

Budżet wielkości 8000000000 euro przeznaczony na pożyczki udzielane przez kasę oszczędnościową (Fonds d'épargne) zarządzaną przez Caisse des Dépôts et Consignations zostal ustalony przez ministra gospodarki na okres 5 lat (lata: 2009-2013). Głównym celem budżetu było ułatwienie realizacji projektów w formule PPP oraz zapewnienie im długoterminowego finansowania. Pierwszeństwo miały pożyczki przeznaczone na realizację wielkich projektów infrastrukturalnych w dziedzinie transportu (rozwój transportu kolejowego, budowa pasów ruchu zarezerwowanych dla transportu komunalnego, rozwój dróg wodnych, naprawa dróg gminnych) na 
kwotę 7000000000 euro oraz inwestycje w szkolnictwo wyższe (budowa kampusów uniwersyteckich) na kwotę 1000000000 euro [Devedjian, Lagarde, 2009, s. 3]. Przyznawane władzom samorządowym pożyczki mogły stanowić maksymalnie 50\% wartości inwestycji. W przypadku wielkich projektów infrastrukturalnych pożyczki udzielane były na okres od 40 do 50 lat.

W celu przyspieszenia realizacji inwestycji publicznych i prywatnych, które miały być lekarstwem na kryzys, francuski rząd zdecydował się na uproszczenie wielu procedur. W szczególności udoskonalono kodeks zamówień publicznych, wprowadzając do toku postępowania wiele usprawnień. Dostosowano m.in. progi i wymagania formalne, dotyczące zamówień publicznych, aby ułatwić do nich dostęp małym i średnim firmom. Wprowadzono większą transparentność procedur oraz równe traktowanie większych i mniejszych podmiotów [Conseil des Ministres ..., 2009, p. 3]. Ustawa LAPCIPP z 17 lutego 2009 r. sprecyzowała definicję PPP, pozwalając żeby część środków finansowych mogła zostać wniesiona do projektu przez jednostkę publiczna. Niemniej jednak, w przypadku umowy PPP, finansowanie powinno w większości spoczywać po stronie podmiotu prywatnego. Wyjątkiem od tej reguły mogły być przedsięwzięcia o znacznych kosztach, przekraczających wartość 40000000 euro [Devedjian, Lagarde, 2009, s. 4]. Ponadto uelastyczniono przepisy urbanistyczne, zachęcając tym samym do inwestycji mieszkaniowych.

W planie ożywienia francuskiej gospodarki znalazły się liczne propozycje adresowane do przedsiębiorców. Przede wszystkim wprowadzono wiele ulg podatkowych dla podmiotów gospodarczych podejmujących inwestycje. Firmy zostały całkowicie zwolnione z podatku dochodowego od nowych działan inwestycyjnych oraz prac badawczych (realizowanych do końca 2009 r.). Ponadto, ze zwolnień podatkowych korzystać mogły firmy zatrudniające w 2009 r. mniej niż 10 pracowników. Część środków w ramach plan de relance przeznaczona została na dofinansowanie szkoleń $\mathrm{w}$ przedsiębiorstwach oraz przyjmowanie nowych pracowników. Państwo francuskie wprowadziło także system dopłat publicznych do pensji pracowników. Wspierano $\mathrm{w}$ ten sposób osoby zagrożone: zwolnieniami, redukcją wynagrodzenia lub etatu. Dopłaty do pensji dla najuboższych rodzin, beneficjentów revenu de solidarité active (RSA) wynosiły przeciętnie 200 euro (na rodzinę) [Budget ..., 2009].

Jednym z ważnych elementów plan de relance były inwestycje mieszkaniowe. W samym 2009 r. na budownictwo socjalne zamierzono przeznaczyć kwotę 340000000 euro [Plan de relance de l'économie ..., 2009, p. 1]. W latach 2009-2010 państwo planowało wybudować 100000 mieszkań. Kwota 50000000 euro zamierzano wesprzeć osoby, które zadłużyły się kupując mieszkania. W roku 2009 podwojono pulę środków zarezerwowanych na nieoprocentowane kredyty hipoteczne dla osób kupujących po raz pierwszy mieszkanie. Kolejne 350000000 euro planowano wydać na działalność Narodowej Agencji Odnowy Miast ANRU (Agence Nationale pour la Rénovation Urbaine). Środki te miały zostać wydane głównie na renowację budynków, zwiększająca ich energooszczędność oraz podnosząca bezpieczeństwo ich mieszkańców. Narodowa Agencja Mieszkaniowa (Agence Nationale de l'babitat), otrzymała na swoją działalność 200000000 euro. Kwota 217000000 euro 
przeznaczona została na rozbudowę bazy mieszkań prowizorycznych do dyspozycji osób potrzebujących.

Plan ożywienia gospodarki miał być wprowadzony w życie natychmiastowo. Już w pierwszych miesiącach 2009 r. planowano uruchomić około 1000 pierwszych projektów inwestycyjnych w całej Francji o łącznej wartości powyżej 10000000000 euro. Znalazły się wśród nich m.in.: budowa biblioteki uniwersyteckiej w Breście, budowa Muzeum Cywilizacji Europejskiej i Śródziemnomorskiej w Marsylii, budowa kampusów uniwersyteckich i 10 centrów badań naukowych, budowa aresztów śledczych i sądów, budownictwo socjalne, renowacja budynków miejskich, restauracja ponad 50 katedr [Plan de relance français ..., 2009].

P. Devedjian, minister odpowiedzialny za wdrożenie planu ożywienia francuskiej gospodarki, 26 sierpnia 2009 r. na konferencji prasowej przedstawił stopień jego realizacji. Z 1000 projektów zapowiedzianych w styczniu, 700 zostało rozpoczętych, do końca września liczba ta miała wzrosnąc do 800. Na działania mające na celu pobudzenie wzrostu gospodarczego wydano do tego momentu 18200000000 euro, co stanowiło $56 \% \%^{5}$ budżetu plan de relance [Plan de relance: bilan ..., 2009]. Poręczenia i gwarancje kredytowe na sumę 4400000000 euro wsparły francuskie przedsiębiorstwa. Kwota 1200000000 euro dofinansowano wydatki inwestycyjne przedsiębiorstw państwowych. Inwestycje władz samorządowych zostały wsparte kwotą 3700000000 euro. Największa część środków - 8900000000 euro - sfinansowała ulgi podatkowe dla francuskich przedsiębiorstw.

Budżet plan de relance podlegał nowelizacji i do grudnia 2010 ostatecznie zamknął się w kwocie 38800000000 euro (rysunek 2). Na ulgi podatkowe dla przedsiębiorstw przeznaczono $31,9 \%$ tej kwoty. Niewiele mniej, bo 30,9\% środków, pochłonęły inwestycje publiczne. Na wsparcie finansowe dla przedsiębiorstw w formie poręczeń i gwarancji kredytowych przeznaczono 15\% środków. Działania w ramach filaru „solidarność i mieszkanie” stanowiły $12,8 \%$ budżetu. Na ochronę miejsc pracy zarezerwowano 9,4\% środków finansowych. Należy zauważyć, że 20\% kwoty udzielonych kredytów przeznaczono na budowę ekologicznej gospodarki.

Do końca sierpnia 2009 r. z planu pomocowego skorzystało około 11000 przedsiębiorstw. Najczęstszą formą pomocy były gwarancje kredytowe. Największym sukcesem było jednak wygenerowanie przez rynek 400000 miejsc pracy w małych firmach ${ }^{6} \mathrm{w}$ wyniku wprowadzenia mechanizmu ,zérocharges TPE”, zwalniającego pracodawców z ponoszenia dodatkowych kosztów zatrudnienia ${ }^{7}$. W ciagu dwóch lat plan de relance wsparł finansowo francuskie przedsiębiorstwa kwotą 5300000000 euro. Od końca 2008 r. do grudnia 2010 r. z różnych form wsparcia skorzystało 20100 przedsiębiorstw. Z tej liczby 4000 przedsiębiorstw uzyskało gwarancje

5 W grudniu 2008 r. na plan de relance zamierzano przeznaczyć 26000000000 euro, do sierpnia 2009 r. kwotę tę zwiększono do 32500000000 euro.

6 Firmy zatrudniające we Francji mniej niż 10 pracowników.

7 Do największych kosztów dodatkowych zatrudnienia, ponoszonych przez zatrudniającego należały składki na ubezpieczenie zdrowotne i emerytalne. 
kredytowe, 17200 przedsiębiorstw otrzymało pożyczki średniookresowe, wśród nich 1100 skorzystało z dwóch form wsparcia [Bilan du plan de relance ..., 2011, p. 4].

RYSUNEK 2

\section{Budżet plan de relance, zreralizowane wydatki w latach 2009-2010 (w \%)}

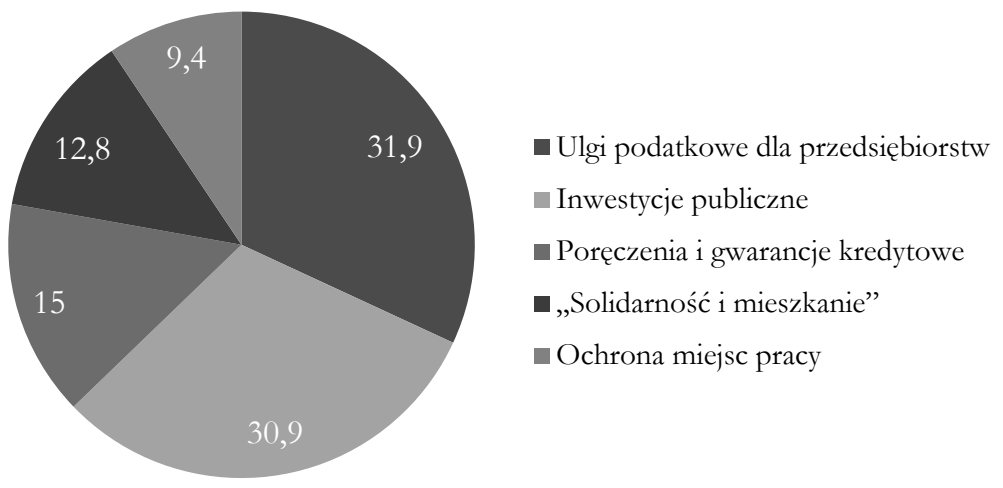

Źródło: [Devedjian, 2010, s. 3].

W przedsiębiorstwach, które otrzymały wsparcie finansowe, łącznie zatrudnionych było 382500 osób. Ponad połowa z nich to były małe firmy, ale prawie połowa zatrudnionych pracowała $\mathrm{w}$ przedsiębiorstwach średnich lub pośrednich ${ }^{8}$. Około 40\% zatrudnionych w przedsiębiorstwach, które otrzymały wsparcie pracowało w sektorze produkcji przemysłowej. Działalność Oséo9 i jej partnerów pozwoliła przedsiębiorstwom pozyskać środki na prowadzenie działalności gospodarczej, których nie otrzymałyby bez gwarancji uzyskanych w ramach planu ożywienia gospodarki. Około 95\% francuskich firm w czasie kryzysu finansowego i gospodarczego miała średnią lub słabą wypłacalność. Te przedsiębiorstwa miałyby problemy z polepszeniem swojej sytuacji, ponieważ finansowanie ich działalności byłoby zwiazzane $\mathrm{z}$ wysokim kosztem uzyskania kredytu, którego oprocentowanie w latach 2009-2010 kształtowało się między 3,3\% a 4,4\%. Ankieta przeprowadzona w maju 2011 r. pokazała, że bez wsparcia finansowego w ramach planu ożywienia $43 \%$ przedsiębiorstw nie utrzymałoby się na rynku [Bilan du plan de relance ..., 2011, p. 5]. Prawie co dziesiąte upadło, pomimo otrzymania pomocy. Dzięki wsparciu finansowemu dla przedsiębiorstw udało się zachować 89000 miejsc pracy, zaś 351000 było chronionych.

\footnotetext{
8 Przedsiębiorstwa, których nie można już zaliczyć do średnich, ale też jeszcze nie do dużych.

9 Oséo to prywatne przedsiębiorstwo realizujące służbę publiczną poprzez finansowanie działalności małych i średnich przedsiębiorstw w celu zapewnienia zatrudnienia i wzrostu gospodarczego. W latach 2008-2010, w ramach plan de relance, odpowiadało za zapewnienie przedsiębiorstwom dostępu do kredytów bankowych.
} 
W planie ożywienia gospodarki 1300000000 euro francuski rząd przeznaczył na Fundusz Innowacji Społecznych (Fonds d'investissement social). Do września 2009 r. udzielił on kredytów o wartości 400000000 euro. Fundusz ten, zajmujący się ograniczaniem wpływu spadku aktywności na poziom zatrudnienia, w pierwszym kwartale 2009 r. wsparł finansowo 183000 pracowników, zatrudnionych na niepełny etat, zapobiegając tym samym zwolnieniom [Plan de relance: bilan ..., 2009]. Od początku kwietnia osoby bezrobotne, nie otrzymujące zasiłku dla bezrobotnych, pracujące jednak wcześniej przez dwa miesiące, otrzymały od funduszu po 500 euro wsparcia. Ponadto fundusz podjął działania mające na celu powstanie nowych miejsc pracy poprzez wniesienie od 70 do $90 \%$ kwoty subwencji dla umów o pracę ze wsparciem (contrat d'accompagnement dans l'emploi $i^{10}$ ).

Słowo solidarność, zostało wymówione aż 4 razy, przez Prezydenta Francji N. Sarkozy'ego 4 grudnia 2008 r. podczas przemówienia w Douai w ciagu zaledwie jednej minuty. Solidarność stanowiła jedną z części plan de relance, na którą przeznaczono 3000000000 euro. Chodzi oczywiście o solidarność z osobami pozbawionymi środków do życia oraz najbiedniejszymi rodzinami. Do początku września 2009 r. kwota 1900000000 euro została przekazana w formie premii solidarnościowej najbiedniejszym rodzinom (200 euro na rodzinę) oraz pomocy finansowej dla ubogich rodzin mających dzieci w wieku szkolnym (150 euro na rodzinę). Ponadto w latach 2009-2010 z budżetu pakietu antykryzysowego opłacono ponad 300000 mieszkań socjalnych.

Ważnym elementem pobudzenia wzrostu gospodarczego we Francji było budownictwo. W budżecie plan de relance zarezerwowano 1000000000 euro na zwiększenie podaży mieszkań socjalnych, renowacje miast i remonty mieszkań. Narodowa Agencja Mieszkaniowa do sierpnia 2009 r. przyznała środki na renowację 24200 mieszkań, generując zamówienia na kwotę 200000000 euro dla branży budowlanej [Plan de relance: bilan ..., 2009].

Sektorem francuskiej gospodarki, który znacznie ucierpiał w wyniku kryzysu finansowego i gospodarczego, był sektor motoryzacyjny. Pomoc dla branży motoryzacyjnej stanowiącej około $10 \%$ PKB była ważnym elementem planu ożywienia gospodarki. Kluczowe francuskie marki - Renault i Peugeot-Citroën - otrzymały po 3000000000 euro wsparcia kredytowego na okres 5 lat. Państwo wsparło finansowo banki kredytowe dwóch wspomnianych marek oraz ich najważniejszych poddostawców. Koncerny samochodowe otrzymały też około 2000000000 euro dotacji na badania rozwojowe. Priorytetem były tu ekologiczne technologie samochodowe i ograniczenie emisji zanieczyszczeń.

W ramach planu ratowania francuskiego przemysłu motoryzacyjnego państwo wprowadziło ulgi podatkowe, szacowane początkowo na kwotę 200000000 euro, dla osób, które dokonałyby zamiany starego samochodu na nowy. Właściciele, którzy zdecydowali się na taki krok, mogli liczyć na 1000 euro ulgi. Do końca sierpnia

10 CAE - rodzaj umów o pracę, w których pracodawca otrzymuje pomoc finansową mającą na celu obniżyć koszty pracy. 
2010 r. skorzystało z niej 1000000 osób, przeznaczono na ten cel 940000000 euro [Bilan du plan de relance ..., 2011, p. 3].

Do walki z kryzysem Francja wykorzystała znaczny budżet plan de relance, ale także rozbudowaną sieć instytucji mających na celu stymulowanie wzrostu gospodarczego. Instytucje takie jak: Fundusz Depozytów, Narodowa Agencja Odnowy Miast, Narodowa Agencja Mieszkaniowa, Fundusz Inwestycji Społecznych (Fonds d'investissement social), otrzymały dodatkowe środki finansowe na swoją działalność. Należy podkreślić, że we francuskim modelu gospodarczym duże znaczenie odgrywał i nadal odgrywa sektor publiczny oraz interwencjonizm państwowy.

\section{Realizacja plan de relance}

Struktura budżetu plan de relance była prosta, podporządkowana założeniu szybkiego podziału kredytów na lata 2009-2010. W tym celu stworzone zostały trzy programy o numerach 315, 316 i 317 [Commission des finances ..., 2010, p. 4]. Pierwszy $\mathrm{z}$ nich programme exceptionnel d'investissement public, program nadzwyczajnych inwestycji publicznych zawierał zbiór wszystkich inwestycji przewidzianych, żeby zagwarantować przyśpieszenie realizacji projektów z zakresu budownictwa lub infrastruktury w tym inwestycji cywilnych i wojskowych państwa, z wyłączeniem budownictwa socjalnego, przypisanego do programu 317. Drugi program, nazwany soutien exceptionnel à l'activité économique et à l'emploi, nadzwyczajne wsparcie działalności ekonomicznej i zatrudnienia, skupiał kredyty przeznaczone na bezpośrednie wsparcie dla przedsiębiorstw, w szczególności małych i średnich, silnie narażonych na skutki kryzysu oraz aktywna politykę na rynku pracy. Program o numerze 317, effort exceptionnel en faveur du logement et de la solidarité, nadzwyczajny wysiłek na rzecz zakwaterowania i solidarności, obejmował działania mające na celu ożywić politykę mieszkaniową oraz zwiększyć wartość nabywczą najuboższych rodzin. Wielkość kredytów AE 11 i CP 12 otwartych w ramach poszczególnych programów w latach 2009-2010 przedstawiono w tabelach 1 i 2.

Analizując dane zawarte w tabelach 1 i 2 należy zauważyć, że w momencie wprowadzenia plan de relance większość wydatków antykryzysowych przewidziana była na rok 2009. Planowano otworzyć 100\% AE i 87\% CP przewidzianych na dwa lata. Zmiany w budżecie w ciagu roku doprowadziły jednak do otwarcia w 2009 r. $85,3 \%$ AE i $75,4 \% \mathrm{CP}^{13}$.

11 We francuskim prawie publicznym autorisations d'engagement (AE) to pozwolenia, uchwalane przez organ decydujący o budżecie państwa, ustanawiające maksymalny poziom wydatków, jakie moga być zrealizowane w ciagu roku. Sa prawomocne tylko w ciagu roku operacyjnego, niewykorzystana kwota może jednak zostać przeniesiona na kolejny rok.

12 Crédit de paiement (CP) - to górny limit wydatków, jakie moga być opłacone w ciagu roku dla gwarancji zobowiązań zakontraktowanych w ramach $\mathrm{AE}$.

13 Budżet z 4 lutego 2009 r. nie przewidywał otwarcia dodatkowych AE w 2010 r., podobnie jak niektórych CP, które miały zapewnić realizacje pewnych mechanizmów antykryzysowych realizowanych w 2009 r., które musiały zostać jednak przerwane pod koniec roku. 
TABELA 1

Kredyty otwarte w 2009 r. (w mln euro)

\begin{tabular}{|l|c|c|c|c|}
\hline & $\mathbf{3 1 5}$ & $\mathbf{3 1 6}$ & $\mathbf{3 1 7}$ & Razem \\
\hline $\mathrm{AE}$ & 4101 & 6715,5 & 2784 & 13600,5 \\
\hline $\mathrm{CP}$ & 2972 & 7212 & 2376 & 12560 \\
\hline
\end{tabular}

Źródło: [Commission des finances ..., 2010, p. 4].

TABELA 2

Kredyty otwarte w 2010 r. (w mln euro)

\begin{tabular}{|l|c|c|c|c|}
\hline & $\mathbf{3 1 5}$ & $\mathbf{3 1 6}$ & $\mathbf{3 1 7}$ & Razem \\
\hline $\mathrm{AE}$ & - & 2050 & 290 & 2340 \\
\hline $\mathrm{CP}$ & 1454 & 2050 & 598 & 4102 \\
\hline
\end{tabular}

Źródło: [Commission des finances ..., 2010, p. 5].

Przyjrzenie się stopniowi wdrożenia poszczególnych programów pozwala stwierdzić, w jakim wymiarze ogłoszona przez Prezydenta Francji N. Sarkozy’ego w Douai polityka antykryzysowa została zrealizowana. Oczywiście nie da to żadnej informacji na temat efektywności wydatków $\mathrm{w}$ ramach plan de relance, ale pokazuje ile $\mathrm{z}$ tego, co planowano zrobić, zrealizowano. Kolejnym krokiem będzie analiza wykonaniu programów na poziomie operacyjnym.

Suma wykorzystanych w 2009 r. środków w ramach: programu nadzwyczajnych inwestycji publicznych, programu nadzwyczajnego wsparcia działalności ekonomicznej i zatrudnienia oraz programu nadzwyczajnego wysiłku na rzecz zakwaterowania i solidarności wyniosła 24605630000 euro. Z przeznaczonych środków AE nie wykorzystano tylko 4,2\% zaś CP - 7,8\%. Stopień realizacji plan de relance w $2009 \mathrm{r}$. należy uznać zatem za relatywnie wysoki. W tabeli 3 przedstawiono bilans wydatków w ramach planu ożywienia francuskiej gospodarki w 2009 r.

Inny obraz wyłoni się, gdy przyjrzymy się wykonaniu programów na poziomie operacyjnym, programów ministerialnych i podmiotów będących odbiorcami środków. W tabeli 4 przedstawiono wykorzystanie kredytów w ramach trzech programów w 2009 r.

TABELA 3

Bilans wydatków w ramach plan de relance w 2009 r. (w mln euro i \%)

\begin{tabular}{|l|c|c|c|c|}
\hline & $\mathbf{3 1 5}$ & $\mathbf{3 1 6}$ & $\mathbf{3 1 7}$ & Razem \\
\hline AE otwarte & 4101 & 6715,5 & 2784 & 13600,5 \\
\hline AE przelane & 2932,22 & 710,8 & 405 & 4048,02 \\
\hline $\begin{array}{l}\text { AE wykorzystane w zarządzaniu } \\
\text { bezpośrednim }\end{array}$ & 1147,79 & 5668 & 2159,74 & 8975,53 \\
\hline $\begin{array}{l}\text { Suma wykorzystanych AE } \\
\% \text { AE otwartych }\end{array}$ & $\begin{array}{c}4080,01 \\
99,5\end{array}$ & $\begin{array}{c}6378,8 \\
95,0\end{array}$ & $\begin{array}{c}2564,74 \\
92,1\end{array}$ & $\begin{array}{c}13023,55 \\
95,8\end{array}$ \\
\hline
\end{tabular}




\begin{tabular}{|l|c|c|c|c|}
\hline & $\mathbf{3 1 5}$ & $\mathbf{3 1 6}$ & $\mathbf{3 1 7}$ & Razem \\
\hline CP otwarte & 2972 & 7212 & 2376 & 12560 \\
\hline CP przelane & 2032,53 & 1206,97 & 300,97 & 3540,47 \\
\hline $\begin{array}{l}\text { CP wykorzystane w zarządzaniu } \\
\text { bezpośrednim }\end{array}$ & 694,42 & 5432,16 & 1915,03 & 8041,61 \\
\hline $\begin{array}{l}\text { Suma wykorzystanych CP } \\
\text { \% CP otwartych }\end{array}$ & 2726,95 & $\begin{array}{c}6639,13 \\
92,1\end{array}$ & $\begin{array}{c}2216 \\
93,3\end{array}$ & $\begin{array}{c}11582,08 \\
92,2\end{array}$ \\
\hline
\end{tabular}

Źródło: [Commission des finances ..., 2010, p. 6].

TABELA 4

Wykorzystanie kredytów w ramach poszczególnych programów w 2009 r. (w mln euro i \%)

\begin{tabular}{|l|c|c|c|c|}
\hline & $\mathbf{3 1 5}$ & $\mathbf{3 1 6}$ & $\mathbf{3 1 7}$ & Razem \\
\hline CP otwarte & 2972 & 7212 & 2376 & 12560 \\
\hline $\begin{array}{l}\text { CP wykonane na poziomie } \\
\text { programu }\end{array}$ & 2726,95 & 6639,13 & 2216 & 11582,08 \\
\hline \% CP otwartych & 91,75 & 92,06 & 93,27 & 92,21 \\
\hline $\begin{array}{l}\text { CP wykonane na poziomie opera- } \\
\text { cyjnym programu i podmiotów } \\
\text { będących odbiorcami }\end{array}$ & 2392 & 4278,75 & 1786,21 & 8456,96 \\
\hline \% CP otwartych & 80,48 & 59,32 & 75,18 & 67,33 \\
\hline
\end{tabular}

Źródło: [Commission des finances ..., 2010, p. 7].

Stopień wykorzystania środków CP na poziomie operacyjnym wynosi zaledwie $67 \%$. Wynika to głównie z decyzji o dwukrotnym podniesieniu w 2009 roku kapitału Strategicznych Funduszy Inwestycyjnych (Fonds Stratégique d'Investissement), wchodzacych w skład programu 316. Tylko 39,45\% z kwoty 2940000000 euro, zostało do końca 2009 roku wykorzystane, co rzutowało na stopień wykonalności programu 316 jak i całego plan de relance. W przypadku wyłączenia Strategicznych Funduszy Inwestycyjnych, stopień wykorzystania środków na poziomie operacyjnym wyniósłby 75,85\% [Commission des finances ..., 2010, p. 7]. Jest to wynik o wiele gorszy niż $92,2 \%$ jaki został osiagnięty w przypadku wykorzystanych CP jako procent otwartych CP.

Inny obraz plan de relance wyłania się, gdy przyjrzymy się stopniowi realizacji poszczególnym podprogramów. W tabelach 5,6 i 7 pokazano realizację poszczególnych elementów programów: 315, 316, 317 w 2009 r. 
TABELA 5

Realizacja programu 315 w 2009 r.

\begin{tabular}{|c|c|c|c|c|c|c|c|c|}
\hline \multirow[t]{3}{*}{ Program 315} & \multicolumn{2}{|c|}{$\begin{array}{c}\text { Suma } \\
\text { otwartych } \\
\text { kredytów } \\
\end{array}$} & \multicolumn{2}{|c|}{$\begin{array}{c}\text { Suma } \\
\text { przelanych } \\
\text { środków }\end{array}$} & \multirow{2}{*}{\multicolumn{2}{|c|}{ Konsumpcja }} & \multirow{2}{*}{\multicolumn{2}{|c|}{$\begin{array}{c}\text { Stopa } \\
\text { realizacji } \\
(w \%)\end{array}$}} \\
\hline & \multicolumn{4}{|c|}{$\mathrm{w}$ mln euro } & & & & \\
\hline & $\mathrm{AE}$ & $\mathrm{CP}$ & $\mathrm{AE}$ & $\mathrm{CP}$ & $\mathrm{AE}$ & $\mathrm{CP}$ & $\mathrm{AE}$ & $\mathbf{C P}$ \\
\hline $\begin{array}{l}\text { Infrastruktura i } \\
\text { inwestycje cywilne }\end{array}$ & 1381,8 & 1047,8 & 1376,85 & 881,4 & 1165 & 802 & 84,61 & 90,99 \\
\hline $\begin{array}{l}\text { Szkolnictwo } \\
\text { wyższe i badania }\end{array}$ & 691 & 605 & 675,01 & 529,61 & 558 & 374 & 82,67 & 70,62 \\
\hline $\begin{array}{l}\text { Obrona i bezpie- } \\
\text { czeństwo }\end{array}$ & 1390 & 825 & 1390 & 825 & 1402 & 821 & 100,86 & 99,52 \\
\hline $\begin{array}{l}\text { Dziedzictwo } \\
\text { narodowe }\end{array}$ & 638,2 & 494,2 & 638,2 & 490,95 & 531 & 395 & 83,2 & $80,46 \%$ \\
\hline Razem & 4101 & 2972 & 4080,06 & 2726,96 & 3656 & 2392 & 89,61 & 87,72 \\
\hline
\end{tabular}

Źródło: [Commission des finances ..., 2010, p. 79-80].

TABELA 6

Realizacja programu 316 w 2009 r.

\begin{tabular}{|c|c|c|c|c|c|c|c|c|}
\hline \multirow[t]{3}{*}{ Program 316} & \multicolumn{2}{|c|}{$\begin{array}{c}\text { Suma } \\
\text { otwartych } \\
\text { kredytów } \\
\end{array}$} & \multicolumn{2}{|c|}{$\begin{array}{c}\text { Suma } \\
\text { przelanych } \\
\text { środków }\end{array}$} & \multirow{2}{*}{\multicolumn{2}{|c|}{ Konsumpcja }} & \multirow{2}{*}{\multicolumn{2}{|c|}{$\begin{array}{l}\text { Stopa } \\
\text { realizacji } \\
\text { w } \%\end{array}$}} \\
\hline & \multicolumn{4}{|c|}{ w mln euro } & & & & \\
\hline & $\mathrm{AE}$ & $\mathbf{C P}$ & $\mathrm{AE}$ & CP & $\mathrm{AE}$ & $\mathbf{C P}$ & $\mathbf{A E}$ & CP \\
\hline $\begin{array}{l}\text { Finansowanie } \\
\text { małych i średnich } \\
\text { przedsiębiorstw }\end{array}$ & 1040 & 1040 & 850 & 850 & 850 & 850 & 100 & 100 \\
\hline $\begin{array}{l}\text { Wpłaty na zamówie- } \\
\text { nia publiczne }\end{array}$ & - & 496,5 & - & 496,17 & - & 483 & - & 97,35 \\
\hline $\begin{array}{l}\text { Dofinansowanie } \\
\text { wymiany starych } \\
\text { samochodów }\end{array}$ & 600,5 & 600,5 & 532 & 531,9 & - & 514 & - & 96,63 \\
\hline $\begin{array}{l}\text { Pomoc w zatrudnia- } \\
\text { niu pracowników } \\
\text { w małych przedsię- } \\
\text { biorstwach }\end{array}$ & 535 & 535 & 535 & 368,11 & - & 200,9 & - & 54,58 \\
\hline $\begin{array}{l}\text { Strategiczne Fun- } \\
\text { dusze Inwestycyjne }\end{array}$ & 2940 & 2940 & 2940 & 2940 & - & 1160 & - & 39,45 \\
\hline Dystrybucja CESU & 300 & 300 & 300 & 276 & - & 274,9 & - & 99,6 \\
\hline $\begin{array}{l}\text { Aktywna polityka } \\
\text { na rynku pracy }\end{array}$ & 1300 & 1300 & 1221,81 & 1176,97 & 834,56 & 795,91 & 68,30 & 67,62 \\
\hline Razem & 6715,5 & 7212 & 6378,81 & 6639,15 & 1684,56 & 4278,71 & - & 64,45 \\
\hline
\end{tabular}

Źródło: [Commission des finances ..., 2010, p. 81-82]. 
TABELA 7

Realizacja programu 317 w 2009 r.

\begin{tabular}{|c|c|c|c|c|c|c|c|c|}
\hline \multirow[t]{3}{*}{ Program 317} & \multicolumn{2}{|c|}{$\begin{array}{c}\text { Suma } \\
\text { otwartych } \\
\text { kredytów }\end{array}$} & \multicolumn{2}{|c|}{$\begin{array}{c}\text { Suma } \\
\text { przelanych } \\
\text { środków }\end{array}$} & \multirow{2}{*}{\multicolumn{2}{|c|}{ Konsumpcja }} & \multirow{2}{*}{\multicolumn{2}{|c|}{$\begin{array}{l}\text { Stopa } \\
\text { realizacji } \\
\quad \text { w } \%\end{array}$}} \\
\hline & \multicolumn{4}{|c|}{$\mathrm{w}$ mln euro } & & & & \\
\hline & $\mathrm{AE}$ & $\mathbf{C P}$ & $\mathrm{AE}$ & $\mathbf{C P}$ & $\mathrm{AE}$ & $\mathrm{CP}$ & $\mathbf{A E}$ & $\mathbf{C P}$ \\
\hline $\begin{array}{l}\text { Wsparcie dla budow- } \\
\text { nictwa socjalnego }\end{array}$ & 410 & 219 & 240 & 142,63 & 102,62 & 29,64 & 42,76 & 20,78 \\
\hline $\begin{array}{l}\text { Przyspieszenie renowa- } \\
\text { cji miast (Działalność } \\
\text { Narodowej Agencji } \\
\text { Odnowy Miast) }\end{array}$ & 350 & 200 & 350 & 200 & 350 & 134 & 100 & 67 \\
\hline $\begin{array}{l}\text { Walka z niegodnymi } \\
\text { warunkami mieszkanio- } \\
\text { wymi i renowacja } \\
\text { prywatnych instalacji } \\
\text { cieplnych }\end{array}$ & 200 & 133 & 200 & 133 & 177,5 & 36,80 & 88,75 & 27,67 \\
\hline $\begin{array}{l}\text { Rozbudowa bazy miesz- } \\
\text { kań prowizorycznych }\end{array}$ & 242 & 242 & 222 & 190,33 & 205,08 & 158,14 & 92,37 & 83,09 \\
\hline $\begin{array}{l}\text { Premia solidarnościowa } \\
\text { dla najuboższych rodzin } \\
\text { (200 euro na rodzinę) }\end{array}$ & 885 & 885 & 885 & 882,77 & 885 & 882,77 & 100 & 100 \\
\hline $\begin{array}{l}\text { Premia dla ubogich } \\
\text { rodzin mających dzieci } \\
\text { w wieku szkolnym } \\
\text { (150 euro na rodzinę) }\end{array}$ & 464 & 464 & 463,74 & 463,26 & 463,74 & 463,26 & 100 & 100 \\
\hline $\begin{array}{l}\text { Pomoc socjalna dla } \\
\text { terenów zamorskich, } \\
\text { revenu supplémentaire } \\
\text { temporaire d'activité }\end{array}$ & 233 & 233 & 204 & 204 & 81,60 & 81,60 & 40 & 40 \\
\hline Razem & 2784 & 2376 & 2564,74 & 2215,99 & 2265,53 & 1786,21 & 88,33 & 80,60 \\
\hline
\end{tabular}

Źródło: [Commission des finances ..., 2010, p. 83].

Przyglądając się poszczególnym podprogramom można stwierdzić, że uwydatniają się znaczące dysproporcje w stopniu ich realizacji. W przypadku programu 315, gdzie średnia stopa realizacji AE w 2009 r. wyniosła 89,61\% a CP - 87,72\%, znacząco od pozostałych składników odbiega podprogram szkolnictwo wyższe i badania. Stopa jego realizacji wyniosła $82,67 \%$ AE i tylko $70,62 \%$ CP. Wynika to z faktu, że większość porozumień z 21 instytucjami uniwersyteckimi, beneficjariuszami kredytów w ramach plan de relance, zostało podpisanych między wrześniem a listopadem 2009 r., 8 z nich zostało zawartych dopiero 21 grudnia 2009 r. [Commission des finances ..., 2010, p. 10]. Opóźnienia przy podpisywaniu umów przesądziły o stosunkowo niskim stopniu realizacji tej części planu 315. W roku 2010 z prze- 
widzianych w budżecie 1454000000 euro, CP udało się przelać 494650000 euro, z czego wykorzystano 469350000 euro, stopa realizacji wyniosła 94,88\% [Fillon, 2011, s. 7]. W tabeli 8 pokazano realizację poszczególnych elementów programu 315 w roku $2010 \mathrm{r}$.

TABELA 8

Realizacja programu 315 w 2010 r. (w mln euro i \%)

\begin{tabular}{|l|c|}
\hline \multicolumn{1}{|c|}{ Program 315 } & Suma otwartych CP \\
\hline Infrastruktura i inwestycje cywilne & 484 \\
\hline Szkolnictwo wyższe i badania & 126 \\
\hline Obrona i bezpieczeństwo & 700 \\
\hline Dziedzictwo narodowe & 144 \\
\hline Suma CP przewidzianych w budżecie & 1454 \\
\hline Suma przelanych CP & 494,65 \\
\hline Konsumpcja CP & 469,35 \\
\hline Stopa realizacji CP $\left(w^{\%} \%\right)$ & 94,88 \\
\hline
\end{tabular}

Źródło: [Fillon, 2011, s. 6-7].

Całościowo gorszy wynik w 2009 r. osiagnął program 316, którego średnia stopa realizacji CP wyniosła tylko $64,45 \%$, pomimo realizacji podprogramów: finansowanie małych i średnich przedsiębiorstw, dystrybucja CESU (chèque emploi service universel - oferty pracy mające ułatwić dostęp do usług domowych takich jak: opieka nad dziećmi, korepetycje, prace w ogrodzie), wpłaty na zamówienia publiczne, dofinansowanie wymiany starych samochodów na poziomie zbliżonym do $100 \%$. Główną przyczyną takiego wyniku była, opisana wyżej, decyzja o podniesieniu kapitału Strategicznych Funduszy Inwestycyjnych. Na to nałożył się słaby wynik podprogramu pomoc $\mathrm{w}$ zatrudnianiu pracowników w małych przedsiębiorstwach, nazywanego zérocharge TPE, zero podatków dla małych przedsiębiorstw, którego stopa realizacji CP wyniosła $54,58 \%$.

Uruchomienie tego mechanizmu było zbyt powolne, dodatkowo z całej kwoty 535000000 euro otwartych kredytów tylko 368110000 było do dyspozycji, pomimo dużego zainteresowania nim przedsiębiorców. Z potencjalnych 3 milionów przedsiębiorców 670 tysięcy poprosiło o pomoc w 2009 r. W tym kontekście zapadła decyzja o przedłużeniu działania tego mechanizmu na rok 2010 i wsparcia go kwotą 410000000 euro. Do kwietnia 2010 r. około milion przedsiębiorców wystapiło z prośbą o wsparcie, wyniosło ono 337700 000, a otrzymało je 315300 przedsiębiorstw [Commission des finances ..., 2010, p. 11]. W całym 2010 r. z kwoty 2050000000 milionów euro AE, przewidzianej w budżecie, udało się przelać 1392850000 euro, z czego wykorzystano 1359170000 euro, co dało stopę realizacji AE na poziomie 97,58\%. Realizacja CP programu 316 w 2010 r. wyniosła 98,82\% [Fillon, 2011a, s. 4-5]. W tabeli 9 pokazano realizacje poszczególnych elementów programu $316 \mathrm{w}$ roku $2010 \mathrm{r}$. 
TABELA 9

Realizacja programu 316 w 2010 r. (w mln euro i \%)

\begin{tabular}{|l|c|c|}
\hline \multirow{2}{*}{ Program 316 } & \multicolumn{2}{c|}{ Suma otwartych kredytów } \\
\cline { 2 - 3 } & AE & CP \\
\hline Finansowanie małych i średnich przedsiębiorstw & 10 & 10 \\
\hline Wpłaty na zamówienia publiczne & - & - \\
\hline Dofinansowanie wymiany starych samochodów & 240 & 240 \\
\hline $\begin{array}{l}\text { Pomoc w zatrudnianiu pracowników w małych } \\
\text { przedsiębiorstwach }\end{array}$ & 410 & 410 \\
\hline Strategiczne Fundusze Inwestycyjne & - & - \\
\hline Dystrybucja CESU & -61 & -37 \\
\hline Aktywna polityka na rynku pracy & 1400 & 1400 \\
\hline Suma AE przewidzianych w budżecie & 2050 & 2050 \\
\hline Suma przelanych kredytów & 1392,85 & 1614,03 \\
\hline Konsumpcja & 1359,17 & 1595,02 \\
\hline Stopa realizacji (w \%) & 97,58 & 98,82 \\
\hline
\end{tabular}

Źródło: [Fillon, 2011a, s. 4-5].

Program 317 w 2009 r. udało się zrealizować w 88,33\% AE i 80,60\% CP, przy czym dwie z siedmiu części w 100\%. Całościowy wynik zaniżył fatalny stopień realizacji podprogramu wsparcie dla budownictwa socjalnego, wyniósł on 42,76\% AE i tylko 20,78\% CP oraz podprogramu walka z niegodnymi warunkami mieszkaniowymi i renowacja prywatnych instalacji cieplnych, który udało się zrealizować w 88,75\% AE, ale tylko 27,67\% CP.

W przypadku tego pierwszego, mechanizm okazał się mało atrakcyjny dla potencjalnych odbiorców i nieliczni zdecydowali się z niego skorzystać. Drugi z nich zakładał przeprowadzenie remontów w 80000 mieszkań w ciagu dwóch lat, czego jednak nie udało się zrealizować. Zadecydował o tym wymóg okazania faktur za przeprowadzone naprawy w celu uzyskania zwrotu kosztów. W budżecie na rok 2010 przewidzianych było 290000000 euro AE i 598000000 euro CP na program 317. Z tej kwoty udało się przelać 130260000 euro AE i 389970000 euro CP, stopa realizacji tych pierwszych wyniosła 99,58\%, drugich - 96,01\% [Fillon, 2011b, s. 4-5]. W tabeli 10 pokazano realizację poszczególnych elementów programu 317 w roku 2010 r.

Do działań interwencyjnych plan de relance, oprócz omówionych programów kredytowych, należy zaliczyć wysiłki władz lokalnych, przedsiębiorstw państwowych w walce z kryzysem gospodarczym. To właśnie do tych podmiotów odwołał się podczas przemówienia w Douai Prezydent Francji N. Sarkozy. 
TABELA 10

Realizacja programu 317 w 2010 r. (w mln euro i \%)

\begin{tabular}{|l|c|c|}
\hline \multirow{2}{*}{ Program 317 } & \multicolumn{2}{c|}{ Suma otwartych kredytów } \\
\cline { 2 - 3 } & AE & CP \\
\hline Wsparcie dla budownictwa socjalnego & 10 & 101 \\
\hline Przyspieszenie renowacji miast & 0 & 150 \\
\hline $\begin{array}{l}\text { Walka z niegodnymi warunkami mieszkaniowymi } \\
\text { i renowacja prywatnych instalacji cieplnych }\end{array}$ & 0 & 67 \\
\hline Rozbudowa bazy mieszkań prowizorycznych & 8 & 33 \\
\hline Premia solidarnościowa dla najuboższych rodzin & $-0,30$ & 1,93 \\
\hline $\begin{array}{l}\text { Premia dla ubogich rodzin mających dzieci w wieku } \\
\text { szkolnym }\end{array}$ & 0,02 & 0,5 \\
\hline Pomoc socjalna (revenu supplémentaire temporaire d'activité) & 280 & 280 \\
\hline Suma AE przewidzianych w budżecie & 290 & 598 \\
\hline Suma przelanych kredytów & 130,26 & 389,97 \\
\hline Konsumpcja & 129,72 & 374,43 \\
\hline Stopa realizacji (w \%) & 99,58 & 96,01 \\
\hline
\end{tabular}

Źródło: [Fillon, 2011b, s. 4-5].

Już pod koniec 2008 r. rząd nakłaniał je do zwiększania wydatków inwestycyjnych. Francuski premier 16 grudnia na konferencji ogłosił, że władze lokalne otrzymaja zwrot podatku od towarów i usług ${ }^{14} \mathrm{w}$ przypadku podjęcia działań inwestycyjnych. FC TVA stanowiły ponad $70 \%$ działań państwa wpływających na wydatki inwestycyjne władz lokalnych [Commission des finances ..., 2010, p. 29]. W praktyce, ze względu na uniwersalny charakter i prostotę mechanizmu zwrotu kosztów, FC TVA okazał się wielkim sukcesem. Władze lokalne chętnie go wykorzystywały, w autonomiczny sposób decydując o inwestycjach, jednocześnie realizując rządowy plan de relance. Popularność tego mechanizmu pokazuje zestawienie kwoty 2500000000 euro, przewidzianych w planie budżetowym na rok 2009, z rzeczywistym jego kosztem, który wyniósł 3852900000 euro. Taki wynik nie powinien jednak dziwić, mając na uwadze wspomniane powyżej zalety oraz powierzenie prefektom przez administrację centralną zadania maksymalizacji liczby podpisanych porozumien $w$ ramach tego mechanizmu. $Z$ informacji podanych przez ministra spraw wewnętrznych wynika, że w ramach mechanizmu FC TVA podpisanych zostało 19540 porozumień, skorzystały z niego 23 regiony, 90 departamentów i 17183 gmin [Commission des finances ..., 2010, p. 35].

W walkę z kryzysem miały zaangażować się nie tylko władze lokalne, ale także przedsiębiorstwa państwowe. Wkład przedsiębiorstw publicznych miał wynieść

14 Odpowiedzialny za to byl Fonds de Compensation (FC TVA) - fundusz kompensacyjny podatku od towarów i usług. 
4000000000 euro z planowanych 26000000000 na walkę z kryzysem [Sarkozy, 2008]. W działania inwestycyjne $\mathrm{w}$ ramach plan de relance miały zaangażować się: EDF $^{15}$, GDF-Suez ${ }^{16}$, Poste ${ }^{17}$, SNCF ${ }^{18}$, RATP ${ }^{19}$. W tabeli 11 przedstawiono zobowiązania inwestycyjne wymienionych przedsiębiorstw państwowych oraz ich realizację.

TABELA 11

Realizacja inwestycji zapowiedzianych przez przedsiębiorstwa państwowe $\mathrm{w}$ ramach plan de relance $\mathrm{w}$ latach 2009-2010 (w mln euro)

\begin{tabular}{|l|c|c|}
\hline \multicolumn{1}{|c|}{ Przedsiębiorstwo } & Zobowiązania inwestycyjne & Inwestycje \\
\hline EDF & 2500 & 500 \\
\hline GDF-Suez & 200 & - \\
\hline Poste & 600 & 200 \\
\hline SNCF & 384 & 197 \\
\hline RATP & 456 & 248 \\
\hline Razem & 4140 & $1145^{*}$ \\
\hline
\end{tabular}

*(bez GDF-Suez)

Źródło: [Commission des finances ..., 2010, p. 60].

Przedsiębiorstwa publiczne, mające mało czasu na zmianę swoich planów inwestycyjnych, nie były w stanie wywiązać się ze swoich zobowiązań. Praktycznie wszystkie odnotowały niską stopę realizacji inwestycji w ramach planu ożywienia gospodarki. EDF, z zapowiedzianych w lutym 2009 r. inwestycji na kwotę 2500000000 euro, zrealizował jedynie 500000000 euro. Wkład poczty francuskiej w plan de relance zapowiedziany na poziomie 600000000 euro w rzeczywistości wyniósł 200000000 euro. SNCF udało się zrealizować inwestycje na kwotę 197000000 euro z ogłoszonych 384000000 euro. Najlepszy wynik odnotował RATP, który z zaplanowanej kwoty 456000000 euro, zrealizował inwestycje za 248000000 euro, co daje stopę realizacji na poziomie $54,39 \%$.

Koszt realizacji plan de relance do końca 2009 r. wyniósł 28600000000 euro. Całkowity budżet planu ożywienia gospodarki podlegał wielokrotnie nowelizacji i do

15 Électricité de France (EDF) - francuskie przedsiębiorstwo państwowe dostarczające energię elektryczna.

16 GDF-Suez - francuska grupa energetyczna, od 24 kwietnia 2015 r. Engie. Należy zauważyć, że pomimo prywatyzacji przedsiębiorstwa w lipcu 2008 r., zostało ona przydzielone do realizacji działań inwestycyjnych $\mathrm{z}$ innymi przedsiębiorstwami publicznymi w ramach planu ożywienia gospodarki.

17 Poste - poczta francuska.

18 Société nationale des chemins de fer français (SNCF) - francuski przewoźnik kolejowy.

19 Régieautonome des transportsparisiens (RATP) - przedsiębiorstwo odpowiadające za transport publiczny w Paryżu. 
grudnia 2010 r. osiagnął wielkość 38800000000 euro [Devedjian, 2010, s. 3]. W tabeli 12 przedstawiono koszt budżetowy środków podatkowych dla 2009 r. ${ }^{20}$

TABELA 12

Koszt budżetowy plan de relance w 2009 roku (w mln euro)

\begin{tabular}{|l|c|c|}
\hline \multicolumn{1}{|c|}{ Środki podatkowe } & $\begin{array}{c}\text { Prognozowany } \\
\text { koszt w 2009 r. }\end{array}$ & $\begin{array}{c}\text { Rzeczywisty } \\
\text { koszt w 2009 r. }\end{array}$ \\
\hline Carry back & 1800 & 5031 \\
\hline Podatek od towarów i usług & 3600 & 6504 \\
\hline Ulgi podatkowe na badania i rozwój & 3800 & 3800 \\
\hline $\begin{array}{l}\text { Nadwyżki podatku dochodowego od osób } \\
\text { prawnych }\end{array}$ & 0 & 0 \\
\hline Przyspieszona amortyzacja & 700 & $*$ \\
\hline Suma środków podatkowych dla przedsiębiorstw & 9900 & 15335 \\
\hline Ulgi podatkowe dla najbiedniejszych rodzin & 1100 & 932 \\
\hline $\begin{array}{l}\text { Podwojenie pułapu pożyczek } \\
\text { z oprocentowaniem 0\% }\end{array}$ & 600 & $0^{*}$ \\
\hline Suma środków podatkowych dla rodzin & 1700 & 932 \\
\hline Suma środków podatkowych & 11600 & 16267 \\
\hline Zwrot podatku od towarów i usług FC TVA & 2500 & 3853 \\
\hline
\end{tabular}

*(rezultat w 2010 r.)

Źródło: [Commission des finances ..., 2010, p. 60].

\section{Skuteczność działań antykryzysowych - próba oceny}

Wskaźniki, za pomocą których można dokonać oceny plan de relance, dzielą się na 3 grupy. Do pierwszej z nich zaliczamy wskaźniki pokazujące wykorzystanie kredytów (stopa realizacji AE i CP). W drugiej grupie znajdują się wskaźniki fizycznego wykonania poszczególnych zadań w ramach planu ożywienia gospodarki, takie jak ilość budynków poddanych renowacji, ilość zakupionych samochodów dzięki mechanizmowi dofinansowania ich wymiany czy liczba kilometrów wybudowanych dróg. Do ostatniej grupy zaliczymy wskaźniki pokazujące wpływ plan de relance na francuską gospodarkę i zatrudnienie (liczba stworzonych lub uratowanych miejsc pracy). To dzięki tym ostatnim możliwe jest ocenienie skuteczności działań antykryzysowych. Analiza stopnia wdrożenia poszczególnych programów kredytowych w ramach plan de relance oraz wykonania zadań inwestycyjnych przez władze lokalne

20 Autorowi nie udało się pozyskać danych pokazujących wielkość kosztu środków podatkowych dla $2010 \mathrm{r}$. 
i przedsiębiorstwa państwowe, pokazała, w jakim stopniu polityka antykryzysowa została zrealizowana.

Plan de relance pozwolił złagodzić skutki kryzysu gospodarczego, jednak dokładne oszacowanie jego wpływu na poszczególne zmienne makroekonomiczne (PKB, zatrudnienie, poziom cen) jest bardzo trudne. Chąc obliczyć jego dokładny wpływ należałoby napisać alternatywny scenariusz zmian gospodarczych w latach 20092010, w którym rząd francuski nie podejmowałby działań interwencyjnych. Ocena wpływu planu ożywienia na wzrost gospodarczy musi zostać dokonana z wielką ostrożnością. Z jednej strony dostępne prognozy były przeprowadzane w różnych okresach, co stwarza problem z porównywaniem poszczególnych parametrów, z drugiej strony każda z prognoz przyjmuje różne mnożniki dla poszczególnych działań, żeby ocenić ich wpływ na PKB. W tabeli 13 przedstawiono prognozy mnożnikowe dla poszczególnych działań $\mathrm{w}$ ramach plan de relance.

\section{Prognozy mnożnika dla poszczególnych działań antykryzysowych (w \% PKB)}

\begin{tabular}{|c|c|c|c|}
\hline & $\begin{array}{c}\text { Obnizka podatku od } \\
\text { towaru i usług oraz } \\
\text { podatku dochodowego }\end{array}$ & $\begin{array}{l}\text { Obniżka podatku } \\
\text { dochodowego } \\
\text { od osób prawnych }\end{array}$ & $\begin{array}{l}\text { Transfery } \\
\text { socjalne }\end{array}$ \\
\hline \multirow{2}{*}{ Al Eyd et Barrel } & $0,3^{1}$ & $0,2^{1}$ & $0,1^{1}$ \\
\hline & $0,2^{2}$ & $0,4^{2}$ & $0,2^{2}$ \\
\hline \multirow[t]{2}{*}{ HM Treasury } & 0,1 & 0,5 & - \\
\hline & Obniżka podatków & Konsumpcja prywatna & $\begin{array}{l}\text { Inwestycje } \\
\text { publiczne }\end{array}$ \\
\hline \multirow{3}{*}{ INSEE et DGTPE } & $0,5^{3}$ & \multirow{3}{*}{0,5} & \\
\hline & $0,25^{5}$ & & $\begin{array}{l}1,1^{4} \\
126\end{array}$ \\
\hline & $0,4^{7}$ & & $1,3^{\circ}$ \\
\hline FMI & 0,38 & 0,56 & 1,06 \\
\hline \multirow[t]{2}{*}{ OCDE } & 0,2 & 0,6 & 0,8 \\
\hline & $\begin{array}{l}\text { Aktywna polityka } \\
\text { na rynku pracy }\end{array}$ & Konsumpcja prywatna & $\begin{array}{l}\text { Inwestycje } \\
\text { publiczne }\end{array}$ \\
\hline OFCE & 0,7 & $\begin{array}{c}0,5 \\
0,8^{8}\end{array}$ & 1 \\
\hline
\end{tabular}

${ }^{1}$ pierwszy rok, ${ }^{2}$ drugi rok, ${ }^{3}$ podatek dochodowy od osób fizycznych, ${ }^{4}$ do końca pierwszego roku, ${ }^{5}$ podatki od spółek i osób prawnych, ${ }^{6}$ do końca drugiego roku, ${ }^{7}$ składki, ${ }^{8}$ dla beneficjariuszy minimum socjalnego

Źródło: [Commission des finances ..., 2010, p. 70].

Przyglądając się poszczególnym prognozom można zauważyć, że wydatki inwestycyjne maja przypisany wyższy mnożnik niż pozostałe działania antykryzysowe. Szczególny akcent w planie ożywienia francuskiej gospodarki położony został wła- 
śnie na nie. Zarówno publiczne, jak i prywatne inwestycje, stanowiły około 50\% zmobilizowanych na walkę z kryzysem środków.

Prognozy wpływu planu ożywienia gospodarki na PKB Francji z roku 2009 znacząco się od siebie różniły. Najbardziej pesymistyczne (FMI, Natixis) brały pod uwagę możliwość zwiększenia dynamiki PKB w wyniku plan de relance jedynie o 0,2\% PKB w ciagu dwóch lat. W najlepszym przypadku miał on wygenerować w tym czasie wzrost PKB o $0,74 \%$. Należy zauważyć, że we wszystkich badaniach koszt budżetowy plan de relance przewyższał znacząco jego prognozowany wpływ na PKB. W tabeli 14 przedstawiono prognozowany wpływ planu ożywienia gospodarki na PKB Francji.

TABELA 14

Prognozy wpływu plan de relance na PKB Francji (w \%)

\begin{tabular}{|l|c|c|}
\hline & $\mathbf{2 0 0 9}$ & $\mathbf{2 0 1 0}$ \\
\hline OFCE $^{1}$ & 0,54 & 0,2 \\
\hline INSEE $^{2}$ & \multicolumn{2}{|c|}{$0,5-0,7$} \\
\hline Natixis & \\
\hline FMI $^{4}$ & \multicolumn{3}{|c|}{$0,2-0,4$} \\
\hline
\end{tabular}

${ }^{1} \mathrm{~L}$ 'Observatoire français des conjonctures économiques (OFCE), prognoza nie uwzględnia środków socjalnych i zakłada wydatki w ramach plan de relance na poziomie $1,3 \% \mathrm{PKB}$.

${ }^{2}$ Prognoza przyjmuje wydatki w ramach plan de relance na poziomie $0,8 \% \mathrm{PKB}$.

${ }^{3}$ Prognoza przyjmuje wydatki w ramach plan de relance na poziomie 1,3\% PKB.

${ }^{4}$ Międzynarodowy Fundusz Walutowy (FMI), prognoza zakłada wydatki w ramach plan de relance na poziomie $0,7 \% \mathrm{PKB}$.

Źródło: [Commission des finances ..., 2010, p. 70].

Na skuteczność działań antykryzysowych we Francji należy spojrzeć przez pryzmat stworzonych lub uratowanych miejsc pracy. Minister ds. wdrożenia planu ożywienia P. Devedjian przekonywał, że w wyniku podjętych działań antykryzysowych powstało lub zostało uratowanych 400000 miejsc pracy w 2009 i 2010 r. Komisja Finansowa Zgromadzenia Narodowego szacuje, że w wyniku plan de relance powstało od 18000 do 72000 nowych miejsc pracy. Nawet przy przyjęciu najbardziej optymistycznego scenariusza, wynik ten jest niesatysfakcjonujący jeśli zestawimy go z huczną zapowiedzią ministra gospodarki z grudnia 2008 r. o stworzeniu 100000 miejsc pracy do końca 2009 r. [Commission des finances ..., 2010, p. 72]. Podana przez ministra Devedjian liczba wydaje się zaś znacznie zawyżoną na potrzeby polityki. Raport Oséo mówi o 20100 przedsiębiorstwach, które skorzystały z pomocy od grudnia 2008 r. do grudnia 2010 r., pozwoliło to ochronić 351000 miejsc pracy [Bilan du plan de relance, 2011, s.16]. Ponadto analiza rocznych raportów dwóch z trzech programów kredytowych pozwala stwierdzić, ile miejsc pracy zostało stworzonych lub uratowanych w kluczowym 2009 r. Dzięki kredytom z programu 315 stworzono lub uratowano 18337 miejsc pracy, kredyty z programu 317 stworzyły lub uratowały 92603 miejsca pracy [Commission des finances ..., 2010, p. 73]. 
W roku 2009 stopa bezrobocia we Francji wzrosła z 7,4\% do 9,1\%, na koniec 2010 r. spadła do 8,8\% [INSEE, Taux de chômage au sens du BIT].

Koszt planu ożywienia gospodarki, realizowanego w latach 2009-2010, wyniós1 38800000000 euro. Kwota ta miała znaczacy wpływ na pogorszenie się stanu finansów publicznych we Francji. W roku 2009 deficyt budżetowy wyniósł 7,2\% PKB, w wyniku czego dług publiczny wzrósł do 78,9\% PKB. Rok później deficyt budżetowy stanowił 6,8\% PKB, a dług publiczny osiagną poziom 81,6\% PKB [INSEE, Déficit au sens de Maastricht, Dette au sens de Maastricht].

\section{Podsumowanie}

W artykule zebrano, uporządkowano oraz podjęto próbę oceny francuskich działań antykryzysowych z lat 2008-2010, które są zagadnieniem kontrowersyjnym. $Z$ jednej strony zastosowane środki stymulowały gospodarkę i wpłynęły pozytywnie na wzrost PKB Francji, z drugiej strony doprowadziły do znacznego wzrostu długu publicznego.

Dokonanie oceny efektywności francuskich działań antykryzysowych jest niesłychanie trudne. Należy zauważyć, że zmiany zachodzące we francuskiej gospodarce w latach 2009-2010 w wyniku kryzysu utrudniały realizację plan de relance, który został opracowany pod koniec 2008 r. na bazie pewnych założeń. Ponadto, niemożliwe wydaje się oddzielenie efektów planu ożywienia gospodarki od zmian koniunkturalnych. Trudność stwarza również przypisanie rangi kosztowi wprowadzenia plan de relance $\mathrm{w}$ postaci wzrostu długu publicznego.

Z przywołanych w tekście badań, przeprowadzonych przez cztery niezależne instytucje, wynika, że koszt budżetowy plan de relance przewyższał znacząco jego prognozowany wpływ na PKB. Te wyniki oraz efekty poszczególnych mechanizmów, odbiegające znacząco od wstępnie zdefiniowanych oczekiwań, przesądzają o umiarkowanym sukcesie plan de relance, którego wizje rozminęły się z rynkową rzeczywistościa.

\section{Literatura}

Bilan du plan de relance, impact des interventions d'OSEO en soutien de la trésorerie des entreprises, octobre 2008 - décembre 2010 Oséo 2011, http://it4.interactiv-doc.fr/catalogues/ plan_de_relance__novembre_2011_pdf_310/pdf/plan_de_relance__novemb re_2011_pdf_310.pdf [data wejścia: 03.07.2018].

Budget 2009: de la maitrise des dépenses au plan de relance 2009, http:/ /www.vie-publique. $\mathrm{fr} /$ actualite/dossier/plf-2009/budget-2009-maitrise-depenses-au-plan-relance. html [data wejścia: 27.06.2018].

Commission des finances, de l'économie générale et du contrôle budgétaire de l'Assemblée nationale La mise en cuvre du plan de relance de l'économie française 2010, https://www.ccomptes. fr/sites/default/files/EzPublish/58_2_58837_plan_relance.pdf [data wejścia: 10.07.2018]. 
Conseil des Ministres Mission plan de relance de l'economie 2009, http://www.economie. gouv.fr/files/finances/presse/dossiers_de_presse/081219relance_economie.pdf [data wejścia: 29.06.2018].

Devedjian P., Lagarde C., 2009, Circulation d'application de l'article 6 de la loi n 2009-122 du 4 février 2009 de finanses rectifictative pour 2009 instituant une garantie de l'Etat et de la loi n 2009-179 du 17 février 2009 pour l'accélération des programmes de construction et d'investissement publics et privés, dans ses dispositions relatives aux contracts de partenariat.

Devedjian P., 2010, Le Bilan du plan de relance 2009-2010, http://www.cher.gouv.fr/ content/download/3611/22148/file/relance_bilan.pdf [data wejścia: 04.07.2018].

Fillon F., 2011, PLR 2010 - extraitdu RAP de la mission: Plan de relance de l'économie, programme 315, www4.minefi.gouv.fr/budget/plf2010/docrap/DRGPGMPGM 315. DOC [data wejścia: 05.07.2018].

Fillon F., 2011a, PLR 2010 - extraitdu RAP de la mission: Plan de relance de l'économie, programme 316, www4.minefi.gouv.fr/budget/plf2010/docrap/DRGPGMPGM 316.DOC [data wejścia: 05.07.2018].

Fillon F., 2011b, PLR 2010 - extrait du RAP de la mission: Plan de relance de l'économie, programme 317, www4.minefi.gouv.fr/budget/plf2010/docrap/DRGPGMPGM 317.DOC [data wejścia: 05.07.2018].

INSEE Déficit au sens de Maastricht - Administrations publiques (APU) - Emplois on actifs - En proportion du produit intérieur brut, https://www.insee.fr/fr/statistiques/serie/ 001710810 [data wejścia: 04.07.2018].

INSEE Dette au sens de Maastricht - Administrations publiques (APU) - Ressources ou passifs - En proportion du produit intérieur brut, https://www.insee.fr/fr/statistiques/ serie/001710845 [data wejścia: 05.07.2018].

INSEE Le produit intérieur brut et ses composantes à prix courants, https:/ /www.insee.fr/ $\mathrm{fr} /$ statistiques $/ 2832646$ ?sommaire $=2832834$ [data wejścia: 21.07.2018].

INSEE Taux de chômage au sens du BIT - Ensemble - France métropolitaine - Données CVS, https://www.insee.fr/fr/statistiques/serie/001688526 [data wejścia: 05.07.2018].

Plan de relance: bilan: d'étape, 2009, http://archives.gouvernement.fr/fillon_version2/ gouvernement/plan-de-relance-bilan-d-etape.html [data wejścia: 18.06.2018].

Plan de relance de l'économie - volet logement, 2009.

Plan de relance français: le gouvernement présente 1.000 projets, 2009, http://www.latribune. $\mathrm{fr} /$ actualites/economie/france/20090201 trib000338280/plan-de-relance-francais-le-gouvernement-presente-1.000-projets-.html [data wejścia: 03.07.2018].

Sarkozy N., 2008, Déclaration de M. Nicolas Sarkozyy, Président de la République, sur le plan de relance de l'économie française, à Douai le 4 décembre 2008, http://discours.viepublique.fr/notices/087003839.html [data wejścia: 29.06.2018]. 